\title{
Is Microcredit Targeted to Poor People? Evidences From a Cambodian Microfinance Institution*
}

\begin{abstract}
Alberto Lanzavecchia
University of Padova, Padova, Italy

This study extends research on the social performance of microfinance institutions. The research methodology is based on Grameen Progress out of Poverty Index ${ }^{\mathrm{TM}}$ (PPI ${ }^{\mathrm{TM}}$ ) for Cambodia applied to a sample of borrowers randomly extracted from a Cambodian microfinance institution's loan portfolio. Dataset has been directly collected through in-house interviews. Main questions discussed here are: (1) Is microcredit targeted to poor people? (2) Has the poverty rate of the sample changed in last six months? and (3) What percentage of male vs. female clients is poor? We found an average poverty likelihood of about $8.1 \%$, estimated at the day of the interview, steady over a period of six months and not statistically different between male and female borrowers. This evidence might be related to business geographical location or targeting. Actually, PPI too much relies on asset ownership rather than on cash flows and saving capacity. Despite the general wisdom microcredit is targeted to the "poorest among the poor people”, this is utterly consistent with a sound and safe (micro)banking activity, aimed at sustainable results. Here comes a call for a triple bottom line performance evaluation on microfinance institutions: economic, social and environmental effects of their activities.
\end{abstract}

Keywords: microcredit, social performance, poverty index, case study, Cambodia

\section{Introduction}

Since the seminal work of Hossain (1988), for more than ten years microfinance has been depicted as an effective pathway out of poverty (Pitt \& Khandker, 1998) and its eradication (Yunus, 2007). Access to financial services is claimed to be a key driver to reach sustainable development goals as long as improvements in

\footnotetext{
*Acknowledgement: The author is grateful to Consorzio Etimos for have introduced the author to Maxima, and in particular to its director Francesca Lo Re for her enthusiasm on sharing ideas and practice in microcredit. The author is highly indebt with Maxima CEO Mr. Uong Kimseng for his strong commitment and logistic support. A special thank goes to Ponnak Kiry, Ear Sokry, and all Maxima's staff who kindly guided us through the fields and into the Cambodian culture. A special acknowledgement goes to Lorenzo Rocco for his valuable support and insights in data analysis. Finally, the author would like to thank participants and discussants at EBES 2011 Annual Conference held in Istanbul and an anonymous referee for helpful comments on an earlier draft. All errors, opinions, and views expressed are the author's own.

Project supported by University of Padova “Azioni di cooperazione universitaria-anno 2010 Program” and by Associazione Emanuela Morelli via a grant to Martina Caneri who shared with the author the task of collecting data trough the fields (her assistance is gratefully acknowledged). Both sponsors did not make any other influences on aim, scope, data, methodology, results and conclusions of this research.

Alberto Lanzavecchia, Ph.D., MSc, assistant professor, School of Economics and Business Administration, Department of Economic Sciences, University of Padova (Italy).

Correspondence concerning this article should be addressed to Alberto Lanzavecchia, Department of Economic Sciences, University of Padova, Italy. E-mail: alberto.lanzavecchia@unipd.it.
} 
healthcare, nutritional advice and education can be sustained only whenever households have increased income, consumption and greater control on financial resources (Littlefield, Morduch, \& Hashemi, 2003; Khandker, 2005; Morduch, 1999). Microfinance Institutions (MFIs) should consequently be supported by government (Hardy, Holden, \& Prokopenko, 2002) and investors since they contribute to develop the financial sector and the rural economy (Holden \& Propenko, 2001) by addressing capital flows to people excluded by the commercial banking.

Nonetheless, the impact of credit on people poverty depends on several factors, such as the credit use, the type of microenterprise and the skills of the borrower (Karnani, 2007). The measurement of how poor people lives would have changed had the microcredit not been granted, is a tough challenge of assessment. Roodman and Morduch (2009), Goldberg (2005), and Duvendack, Palmer-Jones, Copestake, Hooper, Loke, and Rao (2011), among the others, reviewed several studies in microcredit impact evaluation, but the picture they draw is still inconclusive. Overall, unchallenged statistical proof of the impact of microfinance on outcomes such as poverty, women's empowerment, health, and education remains elusive, mainly due to difficulties in creating randomized controlled experiments that are free of bias (Karlan \& Goldberg, 2006).

While impact of microfinance has been questioned, donors and investors experienced great concerns that MFIs might be leaving their social missions behind the quest for profits. As a matter of fact, microcredit industry is becoming quickly an asset class suitable to generate adequate and growing return on capital (Dieckmann, 2007). This trend requires MFIs to be increasingly transparent about the achievements of their declared objectives.

As a result, a call for new specific indicators to measure and track over time the social performance of MFIs activities is emerging-whether or not microfinance is the determinant of people's welfare. ${ }^{1}$ Poverty outreach (e.g., poverty levels of clients at entry and their movement out of poverty over time) is one of them. The objective of poverty assessment is twofold: poverty assessment and poverty targeting. The former intends to determine whether the program reached relatively poor people (within a community or region), the latter to identify in advance poorer households in order to deliver services to them rather than to the relatively better-off or non-poor.

Poverty might be measured in alternative ways either by using existing secondary data or through field research that collects primary data on household's welfare (Zeller, 2004). Grameen Progress out of Poverty Index $^{\mathrm{TM}}$ (PPI ${ }^{\mathrm{TM}}$ ) and USAID Poverty Assessment Tool (PAT) are two examples of scorecards that are gaining credits in the microfinance industry (Ford Foundation, CGAP, \& Social Performance Taskforce, 2010). Since these scorecards differ across countries ${ }^{2}$ and use different algorithms, an MFI could get a different estimate of poverty depending on the methodology applied.

While a large body of literature has been addressed to impact evaluation, monitoring poverty level in MFIs borrowers and, broadly, its social performance is a relatively less explored issue. A growing number of organizations around the world are supposed to monitor poverty outreach and to track changes on poverty level over time. However, in the author's best knowledge there is little evidence on these results ${ }^{3}$.

\footnotetext{
1 The Social Performance Task Force (SPTF), an association between more than 850 members among practitioners, donors and investors, academics and researchers, has been charged with clearly defining social performance and addressing questions about measuring and managing social performance. The STPF is currently working to create a common reporting framework for MFIs which would include standardized social performance indicators.

${ }^{2}$ Currently, 34 and 30 countries are available for PPI and PAT scorecard respectively.

3 As of today only four MFIs get the PPI certification released by the Grameen Foundation. Retrieved September 1, 2011, from http://www.progressoutofpoverty.org/certification.
} 
Should MFIs target the marginally poor or the extremely poor? Morduch (1999, p. 1592) suggests that a dollar increase in income for the very poor borrower has a five times greater impact than the same dollar for the marginally poor borrower. Hence, in terms of poverty alleviation, MFIs should focus on the poorest borrowers first. Nonetheless, as MFIs seek to become financially independent, they would target only the marginally poor (Sengupta \& Aubuchon, 2008, p. 21).

In this study we extend the research on MFI's social performance through a case study. This article shows the results of an empirical application of the standards use of the PPITM for Cambodia within a sample of clients of an MFI. Main questions discussed here are: Is microcredit targeted to poor people? Has the poverty rate of the sample changed in last six months? What percentage of male vs. female clients is poor?

The article is structured as follows: Section 2 will describe the Cambodian economic background and its microcredit sector; Section 3 will introduce the MFI case-study; Section 4 will describe the survey design, data, and methodology of this study; Section 5 will show and discuss the main findings; The last section will conclude with consideration on microfinance practice in the broader context of the Cambodian economic development.

\section{The Case Study Background: Cambodian Economy and Microcredit Sector}

A brief summary of Cambodian economic data and trends is shown in Table 1. While the incidence of poverty has declined from 47.0\% in 1994 to 30.1\% in 2007, it remains higher in countryside and almost absent (lower than 5\%) in Phnom Penh (World Bank, 2006). Thus, policy-makers are faced with a clear challenge as some $77.8 \%$ of Cambodians live in the countryside and fostering urbanization will in part transfer the issue to cities.

Economic growth (narrowly concentrated on garment production, tourism, and construction industries) is urban-focused, with limited linkages to the rural economy. This has led to a rapid increase in inequality over the past decade: Gini index in 2007 reached the value of $44.2 \%$ (38.3\% in 1994) ${ }^{4}$. There is a pressing need to diversify the economy to enable the rural poor to contribute to, and benefit from economic growth.

Table 1

\section{Selected Key Data on Cambodia}

\begin{tabular}{lcrrrrr}
\hline & 2004 & 2005 & 2006 & 2007 & 2008 & 2009 \\
\hline Population (mln) & 13.6 & 13.9 & 14.1 & 14.3 & 14.6 & 14.8 \\
GDP (current US\$, mln) & $5,510.3$ & $6,454.5$ & $7,293.5$ & $8,357.5$ & $9,430.4$ & $9,872.2$ \\
GDP growth (annual \%, LCU) & 10.34 & 13.25 & 10.77 & 10.21 & 6.69 & $(1.87)$ \\
GDP per capita (current US\$) & 403.8 & 465.5 & 517.6 & 583.5 & 647.6 & 666.8 \\
GINI Index (\%, 0 perfect equality, 100 perfect inequality) & 41.9 & & & 44.2 & & \\
Literacy rate, adult total (\% of people ages 15 and above) & 73.6 & & & & 77.6 & \\
Poverty headcount ratio at national poverty line (\% of population) & 34.7 & & & 30.1 & & \\
Poverty headcount ratio at rural poverty line (\% of rural population) & 39.2 & & & 34.7 & & \\
Official exchange rate (LCU per US\$, period average) & 4,016 & 4,093 & 4,103 & 4,056 & 4,054 & 4,153 \\
\hline
\end{tabular}

Note. Source: World Bank.

Microfinance in Cambodia emerged from non-profit microcredit projects initiated by international donors, NGOs, and institutions in the early 1990s to fill the institutional void left by the virtually nonexistent banking

\footnotetext{
${ }^{4}$ Higher than, as a comparison, a 37.8\% recorded in Vietnam in 2006.
} 
sector. The "Law on Banking and Financial Institutions", enacted in November 1999, and the government decree for implementation (Prakas), enacted in early 2000, recognizes three categories of banking institutions:

(1) Commercial banks;

(2) Specialized banks;

(3) Microfinance institutions.

Both registered $^{5}$ and licensed ${ }^{6}$ MFIs must adhere to a strict set of reserve requirements and accounting practices, most of which depend on deposit base and loan portfolio size. In 2007 the National Bank of Cambodia issued new regulations that allowed more freedom in taking deposits from the public. ${ }^{7}$ However, capital requirement has proven difficult to meet for most of Cambodia's existing MFIs, and as of December 2010, only 13 institutions have obtained licenses.

As of December 2010, Cambodia Microfinance Association (CMA) reported 25 active members, including 23 MFIs, one NGO, and one commercial bank-ACLEDA ${ }^{8}$. The industry’s aggregate loan portfolio is heavily concentrated among the largest institutions, with the four largest MFIs (excluding ACLEDA) accounting for over 64.3 percent of the gross loan portfolio (see Table 2). The sector weighted average portfolio at risk (more than 30 days past due) ratio is $1.07 \%$, with a write-off ratio of $0.879 \%$.

Multiple lending, whereby an individual has taken out loans from more than one MFI, is becoming quickly a critical issue, as some clients have taken out four to five loans, which increase the probability of default. These unfavorable cases leave the MFIs to resort to suboptimal actions, including selling the clients' collateral, writing-off the outstanding loan as nonperforming, restructuring or rescheduling the loan, or bringing the client to court (Hoy \& Foelster, 2010).

Table 2

Selected Data on CMA Reporting MFIs (as of December 2010)

\begin{tabular}{llllrrr}
\hline & $\begin{array}{l}\text { Provinces } \\
\text { (out of 24) }\end{array}$ & $\begin{array}{l}\text { Districts } \\
\text { (out of 193) }\end{array}$ & \multicolumn{1}{l}{ Active borrowers } & \multicolumn{3}{c}{ Loan outstanding } \\
& 24 & 176 & 112,872 & \multicolumn{1}{c}{ Mln KHR } & \% \\
\hline PRASAC & 15 & 100 & 238,535 & 11.4 & 425,374 & 24.6 \\
AMRET & 19 & 140 & 43,565 & 4.4 & 234,140 & 13.6 \\
SATHAPANA & 16 & 114 & 47,952 & 4.8 & 179,588 & 10.4 \\
HKL & 10 & 75 & 49,964 & 5.0 & 132,760 & 7.7 \\
CREDIT & 24 & 180 & 251,352 & 25.3 & 128,543 & 7.4 \\
AMK & 17 & 100 & 108,047 & 10.9 & 121,659 & 7.0 \\
VISIONFUND & 16 & 100 & 87,186 & 8.8 & 90,230 & 5.2 \\
TPC & 7 & 56 & 14,395 & 1.5 & 31,179 & 1.8 \\
SEILANITHIH & & & & & & 270 \\
\hline
\end{tabular}

\footnotetext{
${ }^{5}$ An MFI shall be registered if it meets one or more of the following conditions: (1) a loan portfolio outstanding equal to or greater than KHR 100 million; (2) savings mobilized from the general public amounting to KHM 1 million or more; and (3) 100 depositors or more.

${ }^{6}$ Licensing is compulsory for any MFI that meets one or more of the following conditions: (1) a loan portfolio outstanding equal to or greater than KHR 1,000 million; (2) 1,000 borrowers or more; (3) savings mobilized from the general public amounting to KHM 100 million or more; and (4) 1,000 depositors or more.

7 To qualify for the new deposit-taking MFI license, MFIs must have a minimum of 2.5 million USD in capital to ensure adequate deposit protection.

${ }^{8}$ ACLEDA is the dominant player in the market for micro-savings, with over $98 \%$ of the market, and its microfinance loan portfolio accounts for $34 \%$ of the outstanding loans.
} 
(Table 2 continued)

\begin{tabular}{|c|c|c|c|c|c|c|}
\hline & Provinces & Districts & Active borrowers & & Loan outst & \\
\hline & (out of 24) & (out of 193) & Nr. & $\%$ & Mln KHR & $\%$ \\
\hline SAMIC & 7 & 30 & 10,410 & 1.0 & 24,547 & 1.4 \\
\hline CAMCAPITAL & 2 & 11 & 266 & 0.0 & 19,459 & 1.1 \\
\hline IPR & 6 & 22 & 3,578 & 0.4 & 14,173 & 0.8 \\
\hline GCMF & 1 & 8 & 1,411 & 0.1 & 11,537 & 0.7 \\
\hline FIRSTFINANCE & 2 & 12 & 157 & 0.0 & 8,305 & 0.5 \\
\hline MAXIMA & 2 & 15 & 2,587 & 0.3 & 8,293 & 0.5 \\
\hline EAP & 7 & 19 & 193 & 0.0 & 7,668 & 0.4 \\
\hline CHAMROEUN (NGO) & 7 & 37 & 14,936 & 1.5 & 6,802 & 0.4 \\
\hline CBIRD & 5 & 20 & 2,220 & 0.2 & 5,199 & 0.3 \\
\hline FUDF & 4 & 4 & 2,545 & 0.3 & 4,471 & 0.3 \\
\hline FARMERFINANCE & 1 & 5 & 161 & 0.0 & 1,119 & 0.1 \\
\hline YCP & 2 & 9 & 120 & 0.0 & 1,090 & 0.1 \\
\hline Total & & & 992,452 & 100.0 & $1,726,257$ & 100.0 \\
\hline Mean & 9 & 59 & 47,260 & 4.76 & 82,203 & 4.76 \\
\hline Standard deviation & 8 & 58 & 74,985 & 7.56 & 113,743 & 6.59 \\
\hline
\end{tabular}

Note. Source: CMA data (2011).

\section{A Case Study: Maxima}

Maxima Organization for Household Economic Development, headquartered in Phnom Penh, was founded in 2000 with the objective of providing financial services to low income clients through small loans to individuals, groups and small to medium-sized enterprises (SMEs). Registered as an NGO by the Ministry in 2001, one year later it became an MFI for rural credit operator and, three years later, it obtained a full license as an MFI under the official name MAXIMA Mikroheranhvatho Co. Ltd. (hereinafter “Maxima”).

As of the end of December 2010 (CMA, 2011) Maxima runs its activities in the head office in Phnom Penh and in three branches in Kandal province, its business spreads over 15 districts, 79 communes and 262 villages.

Maxima shows a well diversified source of funds, mostly from foreign investors (Consorzio Etimos, Kiva, LMDF, Luxmint-ADA), and a sound and effective risk management performance (see Table 3) which made it suitable to get in 2009 a $\beta$ + rating, with a positive outlook, by the international rating agency M-CRIL. Maxima business is both operationally and financially sustainable. The former is reached by raising enough revenues to cover the operating cost (nominal yield on gross portfolio higher than the operating expense on loan portfolio ratio), the latter by raising funds at market interest rates covered by lending activity (operational self-sufficiency ${ }^{9}$ higher than 1).

Maxima sells amortizing and bullet term loans to individuals ${ }^{10}$, on three different duration (6, 12 or 20 months), at fixed interest rates (between $1.9 \%$ and $2.8 \%$ per month) which depend only on the amount borrowed (less than 1,000 USD, between 1,000 and 2,000 USD, more than 2,000 USD) and the selected way of repaying (e.g., if installments are settled at household's home, an additional spread of 10 basis points is due). As predicted by Stiglitz and Weiss (1981), Maxima sells loans at the fixed interest rate at which the expected return to the bank

\footnotetext{
${ }^{9}$ Defined as the following ratio: Financial Revenue/(Financial Expense + Net Impairment Loss + Operating Expense).

10 Actually, there are two borrowers: the principal and a co-borrower.
} 
is maximized. Unsatisfied borrowers would offer to pay a higher interest rate (or greater collaterals) to the bank, however the bank would not lend to those people, as, from its perspective, such loan is likely to be a worse risk than the average loan at the fixed interest rate.

Table 3

Maxima Selected Operating Data (End of the Year)

\begin{tabular}{|c|c|c|c|c|c|}
\hline & 2006 & 2007 & 2008 & 2009 & 2010 \\
\hline \multicolumn{6}{|l|}{ Outreach } \\
\hline Gross loan portfolio (thousand USD) & 660.6 & 806.2 & $1,373.1$ & $1,717.8$ & $2,049.4$ \\
\hline Number of borrowers (thousand) & 1.6 & 1.6 & 2.1 & 2.4 & 2.6 \\
\hline Average loan per borrower (USD) & 422.6 & 514.5 & 639.8 & 723.9 & 790.0 \\
\hline female (\%) & $86.1 \%$ & $81.8 \%$ & n.a. & $61.1 \%$ & $57.8 \%$ \\
\hline \multicolumn{6}{|l|}{ Risk } \\
\hline PAR $>30$ days & $0.33 \%$ & $0.26 \%$ & $0.25 \%$ & $1.96 \%$ & $0.23 \%$ \\
\hline Write-off ratio & $0.00 \%$ & $0.82 \%$ & $0.04 \%$ & n.a. & $1.29 \%$ \\
\hline \multicolumn{6}{|l|}{ Financial performance } \\
\hline ROA & $4.42 \%$ & $3.60 \%$ & $3.27 \%$ & $3.32 \%$ & $4.72 \%$ \\
\hline ROE & $10.89 \%$ & $11.36 \%$ & $13.25 \%$ & $13.79 \%$ & $17.74 \%$ \\
\hline Yield on gross portfolio (nominal) & $38.58 \%$ & $30.78 \%$ & $29.64 \%$ & $29.04 \%$ & $28.63 \%$ \\
\hline \multicolumn{6}{|l|}{ Efficiency } \\
\hline Cost per borrower (USD) & 84 & 95 & 124 & 124 & 123 \\
\hline Operating expense/loan portfolio & $24.29 \%$ & $20.28 \%$ & $21.11 \%$ & $18.11 \%$ & $16.87 \%$ \\
\hline \multicolumn{6}{|l|}{ Productivity } \\
\hline Borrowers per loan officer & 98 & 92 & 98 & 77 & 81 \\
\hline Personnel allocation ratio & $69.57 \%$ & $70.83 \%$ & $61.11 \%$ & $62.00 \%$ & $58.18 \%$ \\
\hline
\end{tabular}

Note. Source: MIX Market (2011).

Loans are categorized according to their purpose: (1) agriculture; (2) trade and commerce; (3) services; (4) transportation; (5) housing; and (6) family consumption and miscellaneous.

In order get access to credit, a (potential) borrower must have already repaid any other loan previously granted by banks or MFIs: This is the effective way Maxima applies the client protection principle avoidance of over-indebtedness (SPTF, 2011). Optimal borrower's debt repayment capacity is assessed by a Maxima's credit officer, who forecasts the client expected weekly cash flows and then he or she fixes the best sustainable monthly installments. Eventually, if the borrower cannot make his/her payments, he/she is allowed to renegotiate, under the supervision of the village master, the loan contract rather than default.

Cash flows on loans (disbursement and repayments) are settled in dollars, as a consequence, currency risk is mostly transferred (Maxima is mostly funded in US dollars) to borrowers, who get their income in local currency—basically rural people.

\section{Survey Design, Data, and Methodology}

\section{Sampling}

Sample size $(N)$ was determined by the following formula (Grameen Foundation, 2008, p. 64):

$$
N=\left[\frac{\left(Z^{2} x P x(1-P) x D\right)}{E^{2}}\right]
$$


Where:

$Z$ : is the $z$-score is derived from the desired confidence interval;

$P$ : is a guess value for the proportion of the population that it is anticipated will be measured;

$D$ : (in a range of 1-10) is a design effect, the extent to which the sample deviates from random sampling ${ }^{11}$;

$E$ : is the margin of error. ${ }^{12}$

In order to provide at least a 95\% confidence level for a population of 2,500 active borrowers $(P=10 \%)$ with a precision of $5 \%$, and $D=1.5$, a target sample size of 207 was fixed. ${ }^{13}$

We then randomly extract borrowers in a two-stage sampling technique ("strata sampling”): we first randomly selected nine out of 15 districts covered by Maxima and then randomly select borrowers within the selected districts. We excluded from the pick-up list borrowers who ended the relationship with Maxima more than six months before.

\section{Data Collection}

Data used in this study were directly collected from October 11 to November 10, 2010 by in-house interviewing $^{14}$ random selected borrowers.

In case borrowers were unavailable ${ }^{15}$ we phoned from site to Maxima head office asking to randomly extract a new borrower living in the same village to be interviewed on the same day ("random walk" method), if any. If no other extracted borrowers were available to be interviewed on the same day, we would randomly extract a new borrower to be added in the interview list for the following days (IRIS Center, 2011).

At the end of the scheduled interview period we got 230 interviews, of which 216 with full data. Descriptive statistics on sample clients are shown in Tables 4 and 5.

Table 4

Sample Descriptive Statistics

\begin{tabular}{|c|c|c|c|c|c|c|c|c|}
\hline & & Gender & Age & Literacy & Real estate value & Cycle & Amount borrowed & Household members \\
\hline \multirow{2}{*}{ Nr. } & Valid & 230 & 229 & 223 & 225 & 225 & 225 & 230 \\
\hline & Missing & 0 & 1 & 7 & 5 & 5 & 5 & 0 \\
\hline \multicolumn{2}{|c|}{ Mean } & & 43 & 0.76 & 8,005 & 2.71 & $1,111.33$ & 5.8 \\
\hline \multicolumn{2}{|c|}{ Standard deviation } & & 11 & 0.43 & 6,082 & 1.85 & 743.11 & 2.1 \\
\hline \multicolumn{2}{|c|}{ Minimum } & & 18 & 0 & 400 & 1 & 100 & 2 \\
\hline \multicolumn{2}{|c|}{ Maximum } & & 67 & 1 & 50,000 & 9 & 4,500 & 17 \\
\hline
\end{tabular}

"Literacy" is the borrower capacity of reading and writing: on average 76\% of borrowers are able to. This is consistent with the average national literacy rate.

\footnotetext{
${ }^{11} D=1$ means that the sample is a random sample, while $D=10$ means that the sample is intentionally non-random.

${ }^{12}$ A 5\% margin of error combined with a 95\% confidence level means that 95 times out of 100 you expect the score to be accurate within $+/-5 \%$ of the true value.

13 A sample size of 333 would have been fixed according to IRIS Center (2007) methodology.

${ }^{14}$ Each interviewer was accompanied by a Maxima's credit officer, who introduced him/her to the borrower and translated the survey in the local language. An interview would take from 10 to 20 minutes. We are aware of the potential risk of "translation bias": Different results could depend on the translator's personality and the way he/she addressed the questions into the Cambodian culture. However, we hired ten different credit officers, as a consequence the marginal impact, if any, of translation bias is weak.

15 All people we met accepted to be interviewed (e.g., no refusal was recorded).
} 
Table 5

Sample Group Geographical Distribution

\begin{tabular}{lccc}
\hline District & Frequency & Percent & Cumulative percent \\
\hline n.a. & 1 & 0.4 & 0.4 \\
AS & 6 & 2.6 & 3.0 \\
DK & 22 & 9.6 & 12.6 \\
KK & 45 & 19.6 & 32.2 \\
KS & 56 & 24.3 & 56.5 \\
MC & 3 & 1.3 & 57.8 \\
MK & 53 & 23.0 & 80.9 \\
ML & 3 & 1.3 & 82.2 \\
PNL & 26 & 11.3 & 93.5 \\
TK & 15 & 6.5 & 100.0 \\
\hline Total & 230 & 100.0 & \\
\hline
\end{tabular}

"Real estate value" is the dollar value, estimated by the credit officer at the loan grant date, of land and house owned by the household. Although real estates do not formally guarantee the loan, contrary to a common wisdom that microcredit is typically addressed to people who do not own any valuable assets (Pankaj, 1996; Sengupta \& Aubuchon, 2008), we found an average asset value of 8,000 USD (e.g., more than ten times the national GDP per capita).

"Cycle" is the number of repeated loans already granted to the borrower. Since a borrower must have previously reimbursed the earlier loan, this value is a proxy of the length of the relationship between the MFI and its client.

"Amount borrowed" is the value of the last loan granted, either still under amortization or already fully reimbursed (within last six months).

"Household members" is defined as the "number of people who share the same pot" (IRIS Center, 2011).

\section{Methodology}

The survey is based on Schreiner (2009) PPI ${ }^{\mathrm{TM}}$ scorecard designed for Cambodia (hereinafter "PPI for Cambodia") ${ }^{16}$, which collect household primary data on few indicators estimating the likelihood of a household has expenditure to be below the national poverty line ${ }^{17}$, e.g., his/her poverty status.

For each value of any answer to ten questions, points are associated. All points in the scorecard are non-negative integers, and total scores range from 0 (most likely below a poverty line) to 100 (least likely below poverty line). The total scores must be converted into probabilities of being below a poverty line via a look-up table (see Table 6). For example, a score of 16 and 32 get a poverty likelihood of 56.1 percent and 21.9 percent respectively of being below the Cambodian poverty line.

The change in a group's poverty rate between two points in time is estimated as the change in the average poverty likelihood of the households in the group. Of course, poverty could get better or worse, and scoring does

\footnotetext{
${ }^{16}$ PPI for Cambodia is based on ten clear-cut questions, provided in Annex 1.

${ }^{17}$ It is common to define a national line as the food line plus the non-food expenditure observed for households whose food expenditure (not total expenditure) matches the food line. Schreiner (2009) calibrates scores from its single scorecard to poverty likelihoods for nine lines: National, Food, 125\% of national, $150 \%$ of national, $200 \%$ of national, USAID “extreme”, USD1.25/day 2005 PPP, USD2.50/day 2005 PPP, USD3.75/day 2005 PPP.
} 
not indicate what caused change. Poverty scoring plainly estimates change, and it does not indicate the determinant of the change. In particular, estimating microcredit impact on borrowers’ poverty requires knowing what would have happened to participants if they had not been granted the loan.

Table 6

Derivation of Estimated Poverty (National Poverty Line) Likelihoods Associated With Scores

\begin{tabular}{cccc}
\hline Score & Households below poverty line & All households at score & Estimated poverty likelihood \\
\hline $0-4$ & 1,148 & 1,338 & $85.80 \%$ \\
$5-9$ & 1,812 & 2,462 & $73.60 \%$ \\
$10-14$ & 5,866 & 8,619 & $68.06 \%$ \\
$15-19$ & 5,067 & 9,034 & $56.09 \%$ \\
$20-24$ & 6,401 & 14,127 & $45.31 \%$ \\
$25-29$ & 4,669 & 13,625 & $34.27 \%$ \\
$30-34$ & 2,689 & 12,305 & $21.85 \%$ \\
$35-39$ & 1,656 & 12,407 & $13.35 \%$ \\
$40-44$ & 635 & 6,774 & $9.37 \%$ \\
$45-49$ & 169 & 4,818 & $3.51 \%$ \\
$50-54$ & 142 & 3,540 & $4.01 \%$ \\
$55-59$ & 72 & 3,013 & $2.39 \%$ \\
$60-64$ & 0 & 2,544 & $0.00 \%$ \\
$65-69$ & 0 & 1,904 & $0.00 \%$ \\
$70-74$ & 0 & 1,592 & $0.00 \%$ \\
$75-79$ & 0 & 1,078 & $0.00 \%$ \\
$80-84$ & 0 & 693 & $0.00 \%$ \\
$85-89$ & 0 & 87 & $0.00 \%$ \\
$90-94$ & 0 & 0 & n.a. \\
$95-100$ & 0 & 40 & $0.00 \%$ \\
\hline$N 01-5$ & 0 & $100,000$. & stimated poverty
\end{tabular}

Notes. Number of households normalized to sum to 100,000 . Source: Schreiner (2009). ${ }^{*}$ stimated poverty likelihood is the households below poverty line to All households at score ratio.

We basically measured PPI for Cambodia for each individual randomly selected at the time of the interview and at six months before (e.g., we basically asked if there were any changes to response referred to six months before).

\section{Results}

\section{Is Microcredit Targeted to Poor People?}

We found an average poverty likelihood of about $8.1 \%$, estimated at the day of the interview (see Table 7 , left side). This might depend on their location (Phom Pehn and Kandal province): since poverty headcount is higher among rural people, a lower percentage of poor people is expected within Maxima loan portfolio.

Conversely such a low percentage of poor people might be related to Maxima's access to credit process: Maxima's loans seem not be targeted at the poorest people. Again, this might depend either on customers' self-selection bias (people who apply for a credit mostly live very closed to the capital city, where poverty level is relatively lower than in other districts) and by the evidences that MFI, instead of NGOs, do seek for a sound and sustainable financial performance. Portfolio quality indicators are indeed better than the industry average.

\section{Has the Poverty Rate of Maxima Client Sample Changed in Last Six Months?}

We collected data referred to six months before the day of the interview by direct reviewing any changes 
in the value of the ten PPI for Cambodia questions. At a first glance, a little improvement is recorded during six months: sample average poverty likelihood moves from $9.42 \%$ to $8.07 \%$ (see Table 7 , right side).

Table 7

Results

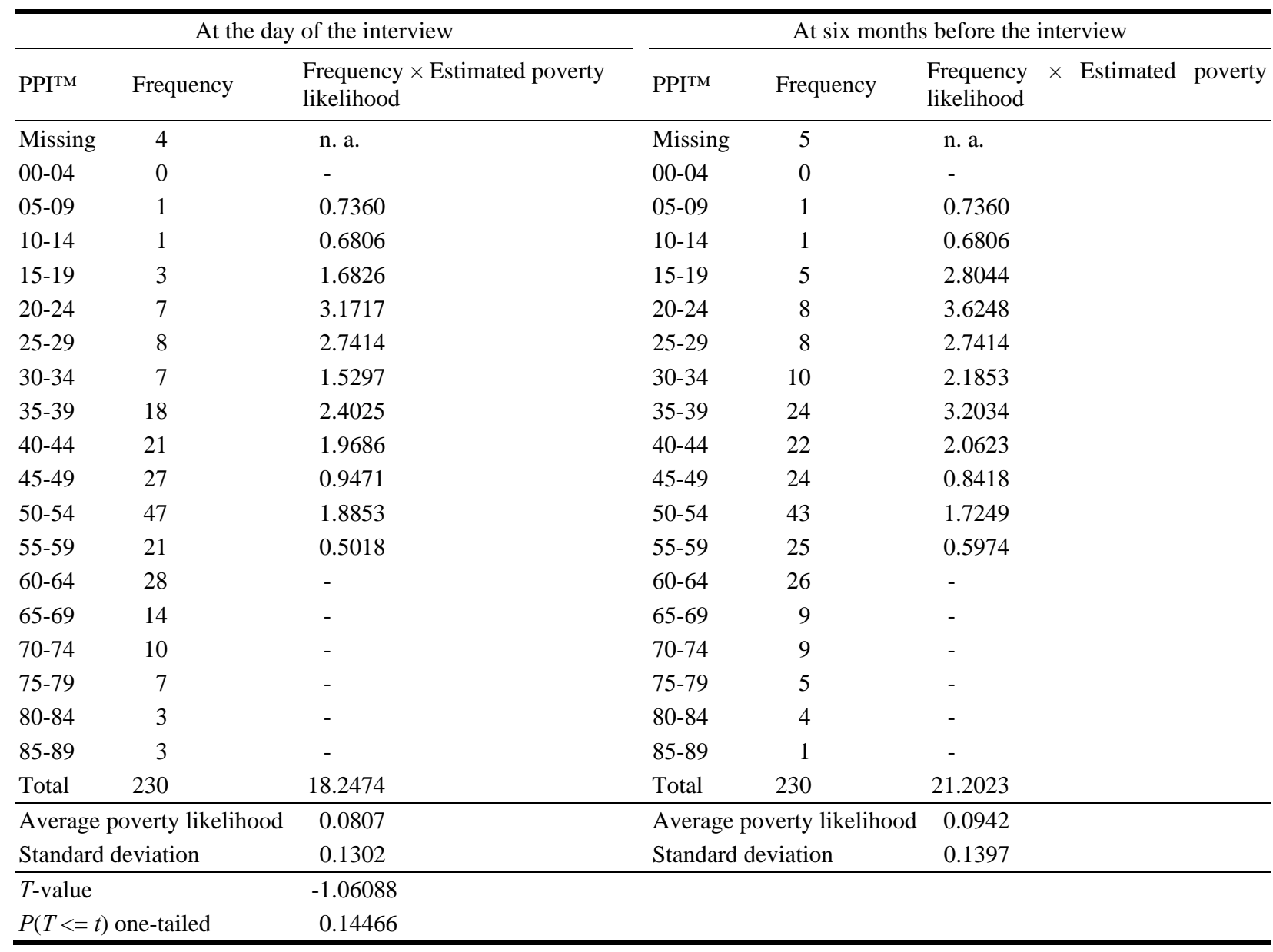

This difference might depend on an effective poverty reduction or on the standard deviation in the sample mean, e.g., by chance. Hence, to check the robustness of this evidence, we run a one-tailed $T$-test on the two sample mean. However, our findings are not statically significant: there is a probability lower than $14.47 \%$ (e.g., well higher than 10\%) that this difference is due to chance (e.g., there are too weak evidences against the null hypothesis that two sample are equal).

Even if loans granted by MFIs fall due within 12 months, changes at poverty level should be accounted over a longer period (Berhane \& Gardebroek, 2011).

\section{What Percentage of Male vs. Female Clients Is Poor?}

Because microcredit programs targeted to poor women have gained prominence, it might appear that women's access to credit is more extensive than the reality suggests. ${ }^{18}$

\footnotetext{
${ }^{18}$ However, in African countries, women still receive less than $10 \%$ of all credit reaching small farmers and only $1 \%$ of the total credit reaching the agricultural sector (Blackden \& Bhanu, 1999).
} 
Table 8 shows frequencies of males and females, their PPI scores and the sample average. At a first glance, average poverty likelihood in women seems to be lower than those recorded in man (7.9\% vs. 8.3\%). Again, we run a $T$-test on the two sample mean to test whether the difference is driven by chance or by a statistical significant difference among two groups. However, the difference between sample means is not statically significant: there is a probability lower than $83 \%$ (e.g., well higher than $10 \%$ ) that this difference is due to chance.

Hence, average poverty likelihood is the same among males and females. As a consequence, this suggests that Maxima does not discriminate on gender poverty in credit access. Male and females share the same (target) level of poverty.

Table 8

PPI Gender Distribution (at the Day of Interview)

\begin{tabular}{|c|c|c|c|c|}
\hline \multirow[b]{2}{*}{$\overline{\mathrm{PPI}}$} & \multicolumn{2}{|r|}{ Male } & \multicolumn{2}{|r|}{ Female } \\
\hline & Frequency & $\begin{array}{l}\text { Frequency } \times \text { Estimated poverty } \\
\text { likelihood }\end{array}$ & Frequency & $\begin{array}{l}\text { Frequency } \times \text { Estimated poverty } \\
\text { likelihood }\end{array}$ \\
\hline Missing & 1 & n. a. & 3 & n. a. \\
\hline 05-09 & 1 & 0.7360 & 0 & - \\
\hline $10-14$ & 0 & - & 1 & 0.6806 \\
\hline $15-19$ & 1 & 0.5609 & 2 & 1.1218 \\
\hline $20-24$ & 3 & 1.3593 & 4 & 1.8124 \\
\hline $25-29$ & 5 & 1.7134 & 3 & 1.0280 \\
\hline $30-34$ & 5 & 1.0926 & 2 & 0.4371 \\
\hline $35-39$ & 4 & 0.5339 & 14 & 1.8686 \\
\hline $40-44$ & 3 & 0.2812 & 18 & 1.6873 \\
\hline $45-49$ & 7 & 0.2455 & 20 & 0.7015 \\
\hline $50-54$ & 17 & 0.6819 & 30 & 1.2034 \\
\hline $55-59$ & 8 & 0.1912 & 13 & 0.3107 \\
\hline $60-64$ & 19 & 0.7360 & 9 & - \\
\hline $65-69$ & 6 & - & 8 & - \\
\hline $70-74$ & 4 & 0.5609 & 6 & - \\
\hline $75-79$ & 4 & 1.3593 & 3 & - \\
\hline $80-84$ & 1 & 1.7134 & 2 & - \\
\hline 85-89 & 1 & 1.0926 & 2 & - \\
\hline Total & 90 & 7.3960 & 140 & 10.8514 \\
\hline \multicolumn{2}{|c|}{ Average poverty likelihood } & 0.0831 & & 0.0792 \\
\hline \multicolumn{2}{|c|}{ Standard deviation } & 0.1439 & & 0.1210 \\
\hline \multicolumn{2}{|l|}{$T$-value } & 0.21134 & & \\
\hline \multicolumn{2}{|c|}{$P(T<=t)$ two-tailed } & 0.83288 & & \\
\hline
\end{tabular}

\section{Conclusion}

Performance measures in microfinance focus almost exclusively on an institution's financial performance. As a result, MFIs have a full range of financial data available to support donors and investors funding process, but there are still little evidences on how they are performing against their social goals or what steps they would need to take to improve their social performance.

Even financial institutions that do not have a social mission might find social performance tools useful 
indeed. In particular, client protection principle "do no harm to clients" is a non-negotiable aspect of social performance that any financial service provider should respect (SPTF, 2011).

This paper enlarges knowledge on microcredit activities by exploring social performance and, namely, poverty outreach.

This study is based on the Progress out of Poverty Index ${ }^{\mathrm{TM}}$ for Cambodia (Schreiner, 2009), applied to a sample of borrowers from a Cambodian MFI shows. We found an average poverty likelihood (to be below the national poverty line) of about $8.1 \%$, estimated at the day of the interview, steady over a period of six months and not statistically different between male and female borrowers. This might be related to business geographical location or a self-selection bias or to access to credit internal procedures (e.g., loans are not targeted at the "poorest among the poor people").

Actually, there might be a third methodological explanation: PPI is a misleading methodology as it is too slow to track poverty predicting indicators over time (e.g., scores and parameters do not change over time). In fast developing countries this is even more problematic since people might suddenly own new assets or items which do not predict correctly the poverty level (e.g., mobile phones or motorbike). From a more general point of view, we found that PPI too much relies on asset ownership rather than on cash flows and saving capacity. As a consequence, it fails to track backward movements at an effective poverty level (since assets still remain even if free cash flow tends to vanish).

The author's modest opinion is that saving capacity is the ultimate measure to track steps taken in a pathway out of poverty. We encourage future researches about it and on head-to-head comparison of poverty level estimates (i.e., PPI vs. PAT) over time within the same sample clients of an MFI, to check for errors in predicting poverty.

Despite the general wisdom that microcredit is targeted to the "poorest among the poor people", our findings are fully consistent with a sound and safety (micro) banking activity, aimed at sustainable results (such as those accounted in Maxima financial reports).

However, here comes a call for a triple bottom line MFI's performance evaluation: economic, social and environmental effects of their activities.

Maxima case study shows that low-income markets can be served on a "sustainable" basis, that is, with full cost recovery and a market return, without subsidy. As a result, in Cambodia the formal financial sector should start to take notice and to service these traditionally marginalized sectors.

\section{References}

Berhane, G., \& Gardebroek, C. (2011). Does microfinance reduce rural poverty? Evidence based on household panel data from northern Ethiopia. American Journal of Agricultural Economics, 93(1), 43-55.

Deutsche Bank Research. (2007). Microfinance: An emerging investment opportunity. Uniting social investment and financial returns. Frankfurt am Main, DE: Dieckmann, R.

Duvendack, M., Palmer-Jones, R., Copestake, J. G., Hooper, L., Loke, Y., \& Rao, N. (2011). What is the evidence of the impact of microfinance on the well-being of poor people? London, UK: EPPI-Centre, Social Science Research Unit, Institute of Education, University of London.

Ford Foundation, CGAP, \& Social Performance Taskforce. (2010). Poverty targeting and measurement tools in microfinance: Progress out of poverty index and the poverty assessment tool. Retrieved from http://www.microfinancegateway.org

Goldberg, N. (2005). Measuring the impact of microfinance: Taking stock of what we know. Grameen Foundation USA Publication 
Series. Washington, D.C.: Grameen Foundation.

Grameen Foundation. (2008). Progress out of poverty index ${ }^{\mathrm{TM}}$. PPI Pilot Training. PPI Participant Guide. Retrieved from http://www.progressoutofpoverty.org

Grameen Foundation. (2011). PPI Certified MFIs. Retrieved from http://progressoutofpoverty.org/certification

Hardy, D. C., Holden, P., \& Prokopenko, V. (2002). Microfinance Institutions and Public Policy. IMF working paper, No. 159. Washington, D.C.: International Monetary Fund.

Holden, P., \& Prokopenko, V. (2001). Financial development and poverty alleviation: Issues and policy implications for developing and transition countries. IMF working paper, No. 160. Washington, D.C.: International Monetary Fund.

Hossain, M. (1988). Credit for alleviation of rural poverty: The Grameen Bank in Bangladesh. Research reports from International Food Policy Research Institute, No. 65. Washington, D.C.: International Food Policy Research Institute.

Hoy, S., \& Foelster, J. (2010). Cambodian microfinance. Industry update. Retrieved from http://www.bwtp.org

IRIS Center. (2007). Introduction to sampling for the implementation of PATs. Retrieved from http://www.povertytools.org/training_documents/Sampling/Introduction_Sampling.ppt

IRIS Center. (2011). Manual for the implementation of USAID poverty assessment tools. Retrieved from http://www.povertytools.org/implementation.html

Karlan, D., \& Goldberg, N. (2006). The impact of microfinance: A review of methodological issues. Working papers. New York, N.Y.: Financial Access Initiative, NYU Wagner Graduate School.

Karnani, A. G. (2007). Employment, not microcredit, is the solution. Ross School of Business Paper No. 1065. Retrieved from http://ssrn.com/abstract=962941

Khandker, S. R. (2005). Microfinance and poverty: Evidence using panel data from Bangladesh. World Bank Economic Review, 19(2), 263-286.

Littlefield, E., Morduch, J., \& Hashemi S. (2003). Is microfinance an effective strategy to reach the millennium development goals? FocusNote No. 24, Washington, D.C.: CGAP.

Morduch, J. (1999). The microfinance promise. Journal of Economic Literature, 37(4), 1569-1614.

Pankaj, S. J. (1996). Managing credit for the rural poor: Lessons from the Grameen Bank. World Development, 24(1), 79-89.

Pitt, M., \& Khandker, S. (1998). The impact of group-based credit programs on poor households in Bangladesh: Does the gender of participants matter? Journal of Political Economy, 106(5), 958-996.

Roodman, D. M., \& Morduch, J. (2009). The impact of microcredit on the poor in Bangladesh: Revisiting the evidence. Working papers No. 174. Washington, D.C.: Center for Global Development.

Schreiner, M. (2009). A simple poverty scorecard for Cambodia. Retrieved from http://www.progressoutofpoverty.org/cambodia

Sengupta, R., \& Aubuchon, C. (2008). The microfinance revolution: An overview. Federal Reserve Bank of St. Louis Review, 90(1), 9-30.

Social Performance Task Force. (2011). Declaration of principles. Retrieved from http://sptf.info

Stiglitz, J. E., \& Weiss, A. (1981). Credit rationing in markets with imperfect information, American Economic Review, 71(3), 393-410.

World Bank. (2006). Cambodia: Halving poverty by 2015? Poverty assessment 2006. Washington, D.C.: World Bank.

Yunus, M. (2007). Creating a world without poverty: Social business and the future of capitalism. New York, N.Y.: PublicAffairs.

Zeller, M. (2004). Review of poverty assessment tools. Working paper. Maryland: The IRIS Center, University of Maryland. 


\begin{tabular}{|c|c|c|c|c|}
\hline \multicolumn{5}{|c|}{ Appendix: Progress out of Poverty Index ${ }^{\mathrm{TM}}$ for Cambodia } \\
\hline \multirow{2}{*}{$\begin{array}{l}\text { Name: } \\
\text { Joined: }\end{array}$} & \multirow{2}{*}{$\begin{array}{l}\text { ID: } \\
\text { Loan officer: }\end{array}$} & \multicolumn{3}{|l|}{ Date (DD/MM/YY): } \\
\hline & & Household size: & & \\
\hline Indicator & \multicolumn{2}{|r|}{ Value } & Points & Score \\
\hline \multirow{7}{*}{$\begin{array}{l}\text { 1. How many members does } \\
\text { the household have? }\end{array}$} & \multicolumn{2}{|c|}{ A. Eight or more } & 0 & \\
\hline & \multicolumn{2}{|l|}{ B. Seven } & 2 & \\
\hline & \multicolumn{2}{|l|}{ C. Six } & 6 & \\
\hline & \multicolumn{2}{|l|}{ D. Five } & 10 & \\
\hline & \multicolumn{2}{|l|}{ E. Four } & 14 & \\
\hline & \multicolumn{2}{|l|}{ F. Three } & 19 & \\
\hline & \multicolumn{2}{|c|}{ G. One or two } & 27 & \\
\hline \multirow{2}{*}{$\begin{array}{l}\text { 2. How many children ages } 7 \\
\text { to } 15 \text { attend school? }\end{array}$} & \multicolumn{2}{|l|}{ A. Not all } & 0 & \\
\hline & \multicolumn{2}{|c|}{ B. All, or no children ages 7 to 15} & 4 & \\
\hline \multirow{3}{*}{$\begin{array}{l}\text { 3. What is the primary } \\
\text { construction material of the } \\
\text { outer wall of the dwelling unit } \\
\text { occupied by the household? }\end{array}$} & \multicolumn{2}{|c|}{$\begin{array}{l}\text { A. Bamboo or thatch, makeshift, salvaged, or improvised materials, other, or no } \\
\text { data }\end{array}$} & 0 & \\
\hline & \multicolumn{2}{|c|}{ B. Wood or logs, plywood, galvanized iron or aluminum, or fibrous cement } & 2 & \\
\hline & \multicolumn{2}{|c|}{ C. Concrete, brick, or stone } & 14 & \\
\hline \multirow{4}{*}{$\begin{array}{l}\text { 4. What type of fuel does the } \\
\text { household mainly use for } \\
\text { cooking? }\end{array}$} & \multicolumn{2}{|c|}{ A. Firewood or other } & 0 & \\
\hline & \multicolumn{2}{|c|}{ B. Charcoal, firewood and charcoal, liquefied } & & \\
\hline & \multicolumn{2}{|c|}{$\begin{array}{l}\text { petroleum gas, kerosene, publicly-provided electricity, gas and electricity, } \\
\text { privately }\end{array}$} & 6 & \\
\hline & \multicolumn{2}{|c|}{ generated electricity, or none/does not cook } & & \\
\hline \multirow{4}{*}{$\begin{array}{l}\text { 5. What toilet facility does the } \\
\text { household have? }\end{array}$} & \multicolumn{2}{|l|}{ A. Open land } & 0 & \\
\hline & B. None & & 4 & \\
\hline & $\begin{array}{l}\text { C. Pit latrine } \\
\text { or other }\end{array}$ & eptic tank, other without septic tank, public toilet, shared toilet, & 6 & \\
\hline & D. Connectec & sewerage & 13 & \\
\hline & A. No bicycl & and no motorcycles & 0 & \\
\hline 6. How many bicycles and & d. One bicyc & and no motorcycles & 4 & \\
\hline motorcycles does the & C. Two bicyc & s, and no motorcycles & 7 & \\
\hline household own? & D. Three or $\mathrm{n}$ & re bicycles, and no motorcycles & 11 & \\
\hline & E. One or mo & motorcycles (regardless of bicycles) & 13 & \\
\hline 7. Does the household own a & A. No & & 0 & \\
\hline bed set? & B. Yes & & 4 & \\
\hline 8. Does the household own a & A. No & & 0 & \\
\hline wardrobe or cabinet? & B. Yes & & 8 & \\
\hline 9. Does the household own a & A. No & & 0 & \\
\hline water pump? & B. Yes & & 5 & \\
\hline 10. Does the household own a & A. No & & 0 & \\
\hline television? & B. Yes & & 6 & \\
\hline Total score & & & & \\
\hline
\end{tabular}

